\title{
Agenda and Criteria for Financial Regulatory Reform ${ }^{1}$
}

\author{
Jane D’Arista and Stephany Griffith-Jones
}

"The more free-market oriented our economy, the greater its need for official financial supervision”. Henry Kaufman, Financial Times, August 6, 2008

\section{Introduction}

The severe turmoil in the most "advanced" financial markets that started in the summer of 2007 follows many deep and costly financial crises in the developing economies during the last twenty five years. This more recent crisis, like previous ones, is the result of both:

a) inherent flaws in the way financial markets operate - such as their tendency to boom-bust behaviour - and

b) insufficient, incomplete and sometimes inappropriate regulation. Financial crises tend to be very costly from a fiscal point of view (i.e,, that of the taxpayer), from their impact on lost output and investment, and from their impact on people, many of whom are both innocent bystanders and poor.

It is therefore urgent and important to reform financial regulation, so that it makes financial crises less likely in the future. Those new systems of financial regulation should attempt to deal with the old unresolved problem of inherent pro-cyclicality of banking as well as financial markets. They should also deal with such new features as the growing scale and complexity of the financial sector, the emergence of new, as yet unregulated actors and instruments, as well as the increased globalization of financial markets. To do this adequately and to avoid regulatory arbitrage, regulation has to be comprehensive.

It is these two broad principles, comprehensiveness and counter-cyclicality, that will provide the framework for our proposals, detailed below.

\footnotetext{
${ }^{1}$ The paper is a draft of a chapter in a forthcoming book on the Financial Turmoil, edited by Joseph Stiglitz, Stephany Griffith-Jones and José Antonio Ocampo.
} 
1. As regards comprehensiveness: for regulation to be efficient, it is essential that the domain of the regulator is the same as the domain of the market that is regulated. Furthermore, lender-of-last resort type facilities provided by national central banks are increasingly being extended to new actors and instruments during the current turmoil. As a result, a corresponding expansion of regulation to actors and activities that have, or are likely to be, bailed out is essential to avoid moral hazard. At a European level, the ECB has been acting quickly and significantly in providing liquidity, but at this European level, "the supervisory function has been almost lacking” (PadoaSchioppa, 2008).The Financial Stability Forum (FSF, 2008) is recommending going further, via the establishment of swap lines among central banks to provide liquidity in different currencies during times of stress. Whilst the internationalization of lender-of-last resort facilities seems both inevitable and desirable, given European and globalized private financial players, it needs to be accompanied by a corresponding and considerable strengthening of the international dimension of financial regulation. If the latter is not done, moral hazard will significantly increase once again as financial activity and risk-taking will grow rapidly in areas where international regulatory gaps exist but there is implicit or explicit coverage by lender-of- last resort facilities.

We will therefore propose comprehensive measures at two levels:

a)transparency for all actors and activities. This will require both registration and disclosure of relevant variables for all financial institutions. This is a pre-condition for comprehensive regulation, but one that will also benefit the counterparties of other financial market participants and investors, as well as macro-economic authorities and

b)comprehensive and equivalent regulation, to cover all entities that invest or lend on behalf of other people, and all activities which they undertake. As we develop below, such regulation needs to be done in ways that protect both liquidity (which we propose could be done through liquidity requirements for individual institutions as well as required reserve holdings by all institutions with national or regional central banks) and solvency (which would be based on capital and would build - though improve - the existing Basle banking regulatory framework while widening its requirements to other financial institutions). 
In fact, adequate liquidity and capital buffers are linked, as sufficient reserves, implying higher levels of liquidity in individual institutions and in the whole system, will alleviate the pressure on capital, in times of stress.

2. A key market failure in the financial system is the pro-cyclical behaviour of most financial actors, which leads to excessive risk-taking and financial activity in good times, followed by insufficient risk-taking and financial activity in bad times. As a consequence, a key principle and desirable feature for efficient regulation is that it is counter-cyclical, to compensate for the inherent pro-cyclical behavior of capital and banking markets. The desirability of such an approach has been increasingly stressed by international institutions, such as the BIS $(2005,2008)$ and leading academics (Ocampo and Chiappe, 2003: Goodhart and Persaud, 2008). This implies varying regulatory requirements for reserves, loan to asset value ratios, capital, provisioning against losses, etc according to the phase of the economic cycle; as discussed below, regulatory variables such as capital could thus be varied according to the growth of total assets, and/or the expansion of assets in particular sectors, e.g. loans for housing. As BIS Chief Economist, William White (2007) pointed out, this would use "monetary and credit data as a basis for resisting financial excesses in general, rather than inflationary pressure in particular.”

The rest of this paper will (in section II) briefly outline the Federal Reserve's policy failures and the evolution of the financial system (emphasizing more features in the U.S.) and their link with the origins of the financial crisis. It will then in Section III develop what we believe are the key principles and criteria for a financial regulation that minimizes systemic risk, and illustrates them with analysis of specific sectors (e.g. off-balance sheet transactions) and important issues (e.g. compensation schemes) Section IV develops our main regulatory proposals, for liquidity and solvency. 


\section{Deregulation, Systemic Change and Policy Failures}

After the eruption of the sub-prime mortgage crisis in the summer of 2007, criticisms of past and present policies of the Federal Reserve and other regulatory authorities became more frequent. In December 2007, the Fed's belated proposals for regulating all mortgage lenders suggested that it was engaged in the proverbial closing of the barn door after the horses were out (Andrews 2007). Why the Fed and other authorities had not thought such restrictions were needed earlier seemed evidence of their ideological commitment to deregulation rather than a pragmatic assessment of developments that could cause market disruption and systemic fragility.

In the case of the Fed, ideology shaped policy outcomes beyond its failure either to condemn or control poor lending practices and fraud. The Fed's monetary influence weakened as it gave priority to deregulation and innovation and abandoned credit flows to the procyclical pressures of market forces, ignoring ways in which monetary policy itself had lost its ability to stabilize financial markets and the economy. It paid no attention to the way that foreign capital inflows drove up the supply of credit and failed to notice the explosion of debt that unchecked credit expansion produced. And, as debt soared, the Fed ignored the asset bubbles it fueled.

Also ignored were critical changes in the structure of financial markets that eroded the ability of regulatory authorities to monitor markets and supervise individual institutions and their increasingly diverse activities. Meanwhile, structural change also undermined the effectiveness of monetary tools used to transmit policy initiatives to the real economy and the Fed's ability to conduct countercyclical operations. As its bailout of Bear Stearns in March 2008 made clear, the Fed recognized that it was facing a systemic crisis but struggled to act systemically. Together with its failure to criticize and curb abusive lending practices, the Fed's passivity in responding to major changes in financial structure and regulation contributed to the prolonged and pervasive reach of the credit crunch that the sub-prime mortgage defaults unleashed.

The following discussion focuses on the policy failures of the Fed and other central banks, arguing that monetary authorities in advanced economies were complicit in creating the conditions that led to the crisis; that, in fact, the crisis could not have occurred absent the excessive liquidity they created. 
While it is clear that the unprecedented escalation in leverage that increased the vulnerability of the financial system to a funding crisis was made possible by deregulation of many activities and products, that escalation also depended on the fuel supplied by loose monetary policy.

Our evaluation of the monetary factors that contributed to systemic weakness and crisis leads us to argue that financial reforms must include a reassessment of the relationship between the central bank, the financial system and the economy. In the recent, heady era of booms based on financial engineering, the impact of imbalances in credit flows to the real economy tended to be overlooked. In the process, central banks and financial institutions seem to have forgotten that finance must serve real economic activity if its own soundness and stability is to survive.

\section{Liquidity, credit growth and asset bubbles}

In the aftermath of the collapse of the major stock indices in 2000, the Fed began to flood US markets with excess liquidity. To address its concerns about the economy's sluggish response to the stimulus already provided and the potential for deflation, it maintained a nominal federal funds rate of one percent from June 2003 through 2004 by generating a continuous stream of liquidity that pushed the real rate of interest into negative territory over the period. As investors' so-called "search for yield" intensified in the low interest rate environment, the unprecedented increase in the availability of funding spurred escalating amounts of leveraged speculation in the form of carry trades, where the effect of borrowing short-term at low rates is to drive down rates on the higher-yielding, long-term assets in which the funds are invested. Excess liquidity was also reflected in narrowed risk premiums and eased credit standards - developments mentioned by former Federal Reserve Chairman Alan Greenspan in his appearance before the Senate Banking Committee in February 2005 but without acknowledgment of their link to excess liquidity (Greenspan 2005).

Before Greenspan's testimony, the June 2004 Annual Report of the Bank for International Settlements had argued that there was in fact a direct link between accommodative monetary policies in the G-3 countries (the US, the Euro-area and Japan) and mounting liquidity in global financial markets. The Report pointed to quantitative measures such as the monetary base, broad money and credit to the private sector - all of which had expanded 
rapidly since 1999 in a large group of countries - as clear evidence of exceptional liquidity growth. Moreover, in 2003 the BIS had specifically criticized the Fed for creating a situation in which a potential US downturn could become more severe due to the domestic debt build-up encouraged by monetary ease and had published research establishing a link between asset bubbles and excessive credit growth. It had also warned about increasing speculation, pointing to a rising volume of leverage in domestic and international financial systems in 2002 that was fueling the credit expansion (BIS 2002, 2003, 2004; Borio and Lowe 2002).

The Fed and other central banks ignored the BIS' warnings despite a major sell-off in bond markets in March 2005 that revealed an escalation in leverage and carry trade activities. They made no effort to address the troubling link between excess liquidity and debt-financed speculation or the even more problematic connection between liquidity and credit growth. Oblivious to the final link in that chain - the asset bubbles inflated by debt and lulled by stable indicators for wholesale and consumer prices, central banks took no action to deal with the inflation in asset prices.

\section{Leveraged capital flows and credit expansion}

Sizable, procyclical capital flows over the last two decades have played an important role in weakening the impact of changes in policy rates on the availability of credit in financial markets. In the US, for example, raising the short-term policy rate in 2004 failed to halt the decline in long-term interest rates or prevent the flood of new borrowing that followed in 2005 and 2006 - a period of exceptionally large capital inflows. But the Fed's efforts to revive credit flows and economic activity by lowering interest rates in a downturn had also proved unreliable as a result of capital outflows during the recession in the early 1990s. At that time, relatively little of the Fed's ample infusion of liquidity was transmitted to the real economy. As interest rates fell, the search for higher yields by domestic and foreign holders of US assets had prompted outflows - mostly to Mexico - that prolonged the recession. Credit growth resumed when the Fed raised interest rates in March 1994 and US and foreign investors returned to US assets, leaving Mexico in crisis.

By the middle of the 1990s, the growth of cross-border carry trade strategies had further undermined the ability of the Fed and other central banks to 
expand or curtail the transmission of liquidity to their national markets. ${ }^{2}$ These strategies, triggered by interest rate differentials on assets denominated in difference currencies, increased the amount of leveraged speculation by financial institutions and fueled yet another set of asset bubbles to add to the string that began in Japan in the 1980s, moved through emerging markets in the 1990s and started to afflict the US and other advanced economies at the turn of the century. The pattern that has developed over the last two decades suggests that relying on changes in interest rates as the primary tool of monetary policy can set off procyclical capital flows that tend to reverse the intended result of the action taken. As a result, monetary policy no longer reliably performs its countercyclical function and its attempts to do so by changing the policy rate may even exacerbate instability.

Throughout 2004 and 2005, for example, borrowing reached truly massive proportions both in the US and abroad. The Fed's measured increases in policy rates had no cooling effect on rising debt levels. In fact, they spurred foreign private inflows into dollar assets at home and abroad by encouraging carry trade strategies that borrowed low interest rate yen to purchase higher yielding dollar assets. Escalating speculation was reflected in recordbreaking growth in borrowing in external banking markets, the great majority of which was channeled to financial institutions and used for position-taking by commercial and investment banks and hedge funds (BIS 2005, 2006).

With capital flows into the US in 2005 rising to twice the amount needed to finance the current account deficit, the US assumed an entrepot function for global markets. Excess flows into dollar assets triggered sizable outflows for investment in higher-yielding emerging market assets (U.S. Department of Commerce 2006). As an excess of dollars from foreign investment on top of current account surpluses flooded their markets, central banks in those countries responded by buying dollars to brake their conversion into local currencies. While their sterilized intervention strategies helped moderate a build-up in domestic liquidity, they also helped mitigate an appreciation of their currencies.

But, needing to invest the dollars they had acquired, emerging market countries bought US treasury securities and other dollar assets and re-

\footnotetext{
${ }^{2}$ Low interest rates in one national market provided an incentive for carry trade strategies that used borrowings in that currency to fund investments in higher-yielding assets denominated in other currencies.
} 
exported the problem back to the US. The accumulation of dollar reserves by these countries augmented the highly liquid conditions in US financial markets, exerting downward pressure on medium and long-term interest rates and fueling another round of capital outflows from the US back to emerging markets as well as continued binge borrowing by US residents.

While 2005 was an extraordinary year in terms of rising liquidity and debt, the pattern of capital flows that year was not unique. Net foreign lending in US credit markets had averaged about 15 percent of the annual supply of funds from the mid-1990s through 2007 (Federal Reserve Flow of Funds). Nevertheless, the advent of monetary ease after 2001 introduced a new dynamic: the generation of liquidity through the spill-over effects of leveraged cross-border investment lows. The round-robin nature of those flows constituted a sorcerer's apprentice scenario that was bound to lead to crisis when uncertainty - from whatever cause - threatened the highly leveraged financial sector's need for funding.

Meanwhile, the rising debt levels of private financial and non-financial sectors were threatening to burst the asset bubbles they had created. The housing bubble that had become apparent in the US and was to burst in the second half of 2007 had been fueled by an extraordinary growth in debt with outstanding credit reaching 352.6 percent of GDP by year-end 2007, up from 255.3 percent in 1997. The rise in household debt over the same decade (from 66.1 to 99.9 percent of GDP) was both a key indicator of the debt bubble and of the growing threat it posed for future spending as debt service took a larger share of disposable income. But the most dramatic development was the jump in the debt of the US financial sector to 113.8 percent of GDP from 63.8 percent only a decade earlier (Ibid.). While the increased borrowing by financial institutions signalled the rise in speculative leverage, it also reflected new funding strategies adopted by a profoundly changed financial system. Those changes and their implications for monetary policy implementation constituted another critical development the Fed ignored.

\section{The slipping transmission belt for monetary policy}

Over the past 30 years, the US financial system has been transformed by a shift in household savings from banks to pension and mutual funds and other institutional investment pools. Between 1977 and year-end 2007, the assets of all depository institutions plummeted from 56.9 percent to 23.7 percent of 
total financial sector assets. Meanwhile, spurred in part by the funding requirements of the Employee Retirement Income Security Act (ERISA) of 1974, the assets of pension funds and mutual funds rose from 21.0 percent to 37.8 percent of the total as these institutional investors came to provide the dominant channels for household savings and investment flows (Table 1).3

Table 1: Outstanding Assets Held by Financial Sectors

\begin{tabular}{|c|c|c|c|c|c|c|}
\hline Amount (\$ billions) & 1957 & 1967 & 1977 & 1987 & 1997 & 2007 \\
\hline Depository Institutions $^{1}$ & $\$ 287.0$ & $\$ 625.1$ & $\$ 1,716.6$ & $\$ 4,455.9$ & $\$ 6,546.5$ & $\$ 13,737.4$ \\
\hline Insurance Companies $^{2}$ & 104.7 & 181.8 & 354.2 & $1,042.7$ & $2,090.3$ & $3,444.2$ \\
\hline Pension Funds ${ }^{\frac{1}{3}}$ & 64.4 & 194.3 & 580.8 & $2,458.5$ & $6,479.2$ & $10,699.1$ \\
\hline Mutual Funds ${ }^{4}$ & 13.1 & 51.8 & 56.8 & 815.3 & $4,177.8$ & $11,170.4$ \\
\hline $\begin{array}{l}\text { GSEs \& Federally Related } \\
\text { Mortgage Pools }\end{array}$ & 8.0 & 25.9 & 162.7 & $1,043.8$ & $2,927.1$ & $7,626.4$ \\
\hline Issuers of Asset-backed Securities & 0.0 & 0.0 & 0.0 & 118.3 & 905.0 & $4,221.0$ \\
\hline Nonbank Lenders $^{5}$ & 21.5 & 51.8 & 140.4 & 470.3 & 799.3 & $1,911.2$ \\
\hline Security Brokers and Dealers & 5.5 & 14.7 & 30.0 & 137.9 & 779.2 & $3,095.3$ \\
\hline Others $^{6}$ & 0.1 & 0.8 & 5.1 & 198.9 & 524.4 & $2,033.9$ \\
\hline Total & 504.3 & $1,146.2$ & $3,046.6$ & $6,640.0$ & $25,228.8$ & $57,938.9$ \\
\hline $\begin{array}{l}\text { Percentage of Total } \\
\text { Financial Sector Assets }\end{array}$ & & & & & & \\
\hline Depository Institutions $^{1}$ & 56.9 & 54.5 & 56.3 & 41.5 & 25.9 & 23.7 \\
\hline Insurance Companies ${ }^{2}$ & 20.8 & 15.9 & 11.6 & 9.7 & 8.3 & 5.9 \\
\hline Pension Funds ${ }^{3}$ & 12.8 & 17.0 & 19.1 & 22.9 & 25.7 & 18.5 \\
\hline Mutual Funds ${ }^{4}$ & 2.6 & 4.5 & 1.9 & 7.6 & 16.6 & 19.3 \\
\hline $\begin{array}{l}\text { GSEs \& Federally Related } \\
\text { Mortgage Pools }\end{array}$ & 1.6 & 2.3 & 5.3 & 9.7 & 11.6 & 13.2 \\
\hline Issuers of Asset-backed Securities & ----- & ----- & ----- & 1.1 & 3.6 & 7.3 \\
\hline Nonbank Lenders ${ }^{5}$ & 4.3 & 4.5 & 4.6 & 4.4 & 3.2 & 3.3 \\
\hline Security Brokers and Dealers & 1.1 & 1.3 & 1.0 & 1.3 & 3.1 & 5.3 \\
\hline Others $^{6}$ & $\begin{array}{l}--- \\
---\end{array}$ & 0.1 & 0.2 & 1.9 & 2.1 & 3.5 \\
\hline
\end{tabular}

SOURCE: Federal Reserve System, Flow of Funds Accounts of the United States

1. Includes commercial banks, savings institutions and credit unions.

2. Includes life and property-casualty insurance companies.

3. Includes private pension funds, state and local government retirement funds and insured pension assets.

4. Includes money market mutual funds, closed-end funds, exchange-traded funds and other mutual funds.

5. Includes finance companies and mortgage companies.

6. Includes real estate investment trusts and funding corporations.

\footnotetext{
${ }^{3}$ The combined assets of pension and mutual funds as a share of financial sector assets were actually higher in 1997 (42.3 percent) when pension fund assets were 25.7 percent of the total than in 2007 when pension funds' holdings slipped to 18.5 percent.
} 
The shift in individual savings from banks to pension and mutual funds produced a symmetrical increase in business borrowing through capital markets. Credit flows to households also moved into the capital markets as mortgage originators such as banks, savings and loan institutions and brokers bundled individual mortgages into pools and sold securities based on those pools to investors. Government-sponsored enterprises (GSEs) such as Fannie Mae and Freddie Mac and federally related mortgage pools played major roles in facilitating this securitization process. Meanwhile, assetbacked securities (ABS) issuers used securitization techniques to fund car loans and other consumer receivables. In the twenty year period between 1987 and 2007, the assets of GSEs and mortgage pools - primarily holdings of mortgages for single-family housing - rose from $\$ 1.0$ trillion to $\$ 7.6$ trillion while assets of ABS issuers jumped from $\$ 118.3$ billion to $\$ 4.7$ trillion.

The implications of these shifts in saving and credit flows have radically altered the way the financial sector functions, reducing the role of direct lending in favor of trading, investment and asset management. Their impact on the transmission of monetary policy initiatives has been profound and was already evident in 1993. At that time, former Fed Chairman Greenspan noted that "the fairly direct effect that open market operations once had on the credit flows provided for businesses and home construction is largely dissipated"; that while the Fed "can still affect short-term interest rates, and thus have an impact on the cost of borrowing from banks, from other intermediaries, and directly in the capital markets.....this effect may be more indirect, take longer, and require larger movements in rates for a given effect on output” (Greenspan 1993, p.3). At the same 1993 conference, former Bundesbank Vice President Hans Tietmeyer's view was somewhat gloomier. He argued that, in a number of countries, deregulation and financial innovation had altered the transmission mechanisms for monetary policy to the real economy and had "generally made it more difficult for monetary policy makers to fulfill their stability mandate” (Tietmeyer 1993, p. 407).

Subsequent events have underscored the accuracy of these remarks. In the 15 years since they were made, however, the major central banks have taken no steps to improve the monetary transmission mechanism. On the contrary, they countenanced further innovation and deregulation and promoted the view that market-based solutions - the Basel Agreement on capital requirements, for example - could replace the quantity controls (reserve and 
liquidity requirements, lending limits and capital controls) that had been targeted for removal by the advocates of liberalization.

As the BIS and others have argued, a prerequisite for stabilizing the crisisstricken global economy is reinstating countercyclical policy initiatives. We argue that this will require both the introduction of countercyclical regulatory reforms and quantitative monetary tools and extending their reach to all segments of the financial system. As discussed in the following sections, the introduction of comprehensive, countercyclical regulatory strategies will bolster the effectiveness of monetary policy implementation by addressing the inherently procyclical bias of the market-based financial system that has evolved in the US and global markets over the last thirty years. 


\section{Criteria and Principles for financial regulatory reform; Some applications}

As discussed in the Introduction, there are two broad principles, comprehensiveness and counter-cyclicality, that need to be adhered to, so that financial regulation is effective in helping ensure financial stability and avoid crises.

\section{Regulation has to be comprehensive}

One of the main causes of the current crisis is the fact that effective regulation covers a diminishing share of total capital and banking markets. As Damon Silvers, Counsel to the AFL-CIO (2008) put it, "the regulatory system is a kind of cheese, where the regulatory holes gradually get larger."

As is often the case it has been true in this crisis that the parts of the financial system that were not regulated at all, or were regulated too lightly, have generated more problems. Because of regulatory arbitrage, growth of financial activity (and risk) moved to unregulated mechanisms (SIVs), instruments (derivatives) or institutions (hedge funds). However, though unregulated, those parts of the shadow financial system were de- facto dependent on systemically important banks via provision of credit, guaranteed liquidity lines or other commitments.

A clear example where lack of capital requirements led to excessive growth of unregulated mechanisms was that of SIVs (structured investments vehicles). It is very interesting that Spanish regulatory authorities allowed banks to have SIVs, but required Spanish banks to consolidate these special purpose vehicles in their accounting, implying that they had the same capital requirements as their other assets (Cornford, 2008; interview material). This eliminated the incentive for such vehicles to grow in Spain, nor did they become a major problem for banks as SIVs became in the U.S.

It is positive that Basle II, unlike Basle I, requires banks to set aside capital to support liquidity commitments to those vehicles; however, those commitments have lower capital requirements for short maturities; furthermore, the Basle Committee is reportedly planning to strengthen these capital requirements to reduce regulatory arbitrage incentives (FSF, 2008, 
op. cit). Though positive, such measures would only be partial. A more comprehensive solution would be for all vehicles and transactions to be put on banks' balance sheets; then there should be no regulatory arbitrage, as risk-weighted capital requirements would be equivalent for all balance sheet activities; furthermore, transparency could automatically became far more comprehensive for banks.

This discussion of SIVs illustrates the fact that the only solution is for comprehensive and equivalent transparency and regulation of all institutions and instruments. This would discourage or even hopefully eliminate regulatory arbitrage and help prevent the build up of excessive systemic risk, which is essential for financial stability. As discussed in the Introduction, the widening of lender-of-last resort facilities - both national and international that is occurring recently further justifies the need of a corresponding increase in comprehensiveness of regulation, to avoid moral hazard.

The task of defining equivalent regulation on assets for all financial institutions and activities, both for solvency and liquidity is essential. ${ }^{4}$

To be more specific, all entities that invest or lend on behalf of other people - using other people's money directly or through some type of leverage need to have relevant transparency requirements and need to be regulated. Within institutions, all their activities need to have equivalent regulation. Therefore, institutions like hedge funds need to be brought into the regulatory domain, as do all off-balance activities of banks.

Specific steps have already been taken towards more comprehensive regulation; for example, U.S. authorities are addressing regulatory gaps in the oversight of entities that originate and fund mortgages, which is clearly welcome. As importantly, there is increasing support for the idea of comprehensive regulation.

For example, an influential EU report (EU 2008) argues that financial regulation should be comprehensive; it especially emphasizes the need to regulate hedge funds and makes specific recommendations to limit the leverage of hedge funds to preserve stability of the EU financial system. Some of the most influential mainstream commentators (see, for example,

\footnotetext{
${ }^{4}$ The technical aspects of how to calculate equivalent liquidity (e.g. reserves) and solvency (e.g. capital) requirements across different institutions and activities requires further study, both by institutions like the BIS and FSF, by national regulators, from both developed and developing countries and by academics.
} 
Roubini, 2008 and Wolf, 2008) are forcefully arguing for comprehensive regulation of all relevant institutions and activities. For example, Martin Wolf writes; "If regulation is to be effective, it must cover all relevant institutions and the entire balance sheet in all significant countries. It must focus on capital, liquidity and transparency.” Furthermore, it is very encouraging that the U.S. Treasury March 2008 Blueprint for Financial Regulatory Reform (U.S. Treasury, 2008), though flawed in some aspects, put forward the idea that financial regulation should be comprehensive, including hedge funds and other private pools of capital.

A key pre-condition for comprehensive regulation is comprehensive transparency of relevant variables. Transparency has also advantages for other actors, such as investors, other market agents and macro-economic authorities.

2. Reducing asymmetries of information between markets actors and regulators is an essential pre-condition for better regulation.

In many cases, regulators genuinely do not know the extent to which risks are increasing, and how these risks are distributed. The more complex and large the financial system the greater the opaqueness and the greater the difficulty to obtain information. Building on the work of Stiglitz (for example, Stiglitz and Weiss, 1981) there is a whole theoretical literature that shows market failures and incorrect incentives lead to private underprovision of information and monitoring by private actors, which gives a rationale for official sector intervention (see Kambhu, et al, 2007, for a view from the Fed).

One example is complex and totally opaque OTC derivatives, which reach massive levels, as highlighted for example by the 2008 FSF report. Possible solutions would be to attempt to standardize such instruments but above all to channel them through clearing house based exchanges, as Soros (2008) suggests for the \$45 trillion credit default swap contracts; currently those that hold the contracts do not know even whether those counterparties are properly protected with capital. This establishment of clearing houses or exchanges, should become obligatory for all OTC derivatives, this would have the benefits of ensuring appropriate margin and capital requirements on each transaction, as well as many other advantages. 
It is interesting that an emerging country, Brazil, has been effective in using regulations and other measures to encourage derivatives to move to established exchanges (Dodd and Griffith-Jones, 2008).

Another, somewhat related example for need for increased transparency is in the case of hedge funds (HFs); on this, there is growing consensus (including by the HF industry itself)) that improved information on HFs and other highly-leveraged institutions (HLIs) would also be valuable to investors, counterparties as well as regulators. As pointed out in a previous paper (Griffith-Jones et al., 2007), it seems appropriate for hedge funds to report market risk, liquidity risk and credit risk, as the Fisher II working group recommended. It also seems essential that HFs report aggregate world wide and country positions, the aggregate level of leverage, and especially the level of long and short positions, and others, such as the level of trading.

In this context, it is encouraging that the UK FSA in June 2008 has introduced a tough disclosure requirement for anyone "short-selling" a significant amount of stock in a company conducting a rights issue; the requirements are stringent in that they oblige short sellers to disclose such positions if they amount to more than $0.25 \%$ of the total shares outstanding. This rule was introduced due to the strong suspicion that hedge funds were short-selling the stock of companies in the middle of rights issue, thus undermining the ability of banks to recapitalize themselves, which is essential for financial stability at present.

It would seem desirable that such disclosure requirements on short and long positions should remain, should be generalized and become the norm internationally.

It is also important to decide with what periodicity and to whom information is to be disclosed; additional important questions are whether this information should be provided by all HFs or only those systematically important.

As regards periodicity of reporting, positions can be reported in real time or with a lag. Though real time reporting would be particularly useful it could be possibly costly, through much of this information must be already privately available. Real time reporting, if publicly available, can either enhance market stability, by encouraging contrarian positions; however, it also risks encouraging herding, if other market actors mimic the positions of 
large actors, e.g. hedge funds (for a good discussions, see De Brower, 2001). The problem of fixed point in time disclosure is the risk of window dressing for the particular moments. The solution may be to require also maximum and minimum positions during this period, to avoid such window dressing.

It would seem best if information would be made publicly available, e.g. on the internet. It may be sufficient if positions are reported in aggregate by class of institution, e.g. bank, securities firms, hedge funds, other HLIs, etc. The aggregate reporting would avoid revealing individual positions.

It seems important to find an institution that would be efficient at collecting and processing speedily such data, without compromising confidentiality. The institution with the best experience in similar data gathering would be the Bank for International Settlements (BIS), which already collects detailed information on banks and other financial institutions. The reputation of the BIS would also ensure confidentiality of individual positions.

Though we have discussed issues of transparency and disclosure in relation to the most opaque actors (hedge funds) and transactions (derivatives), similar criteria need to apply to other opaque actors and, especially to the opaque parts of the banking system.

\section{Regulation has to be counter-cyclical}

It would seem that the most important market failure in financial markets, through the ages, is their pro-cyclicality. Therefore, it is essential that regulation attempts to compensate and curb this (particularly during booms when excessive risk is created) by pursuing counter-cyclical regulation. It is encouraging that finally there is growing agreement among academics, institutions like the B.I.S. (which in its' 2008 Annual Report very forcefully argues for counter-cyclical regulation), and increasingly regulators, about the need for introducing counter-cyclical elements into regulation. It is noteworthy that the 2008 BIS Annual Report rightly argues that the trends toward globalisation, consolidation and securitisation, increase the probability of both excessive behaviour in the boom and costs in the bust, thus increasing the dangerous and negative side effects of financial market pro-cyclical behaviour. This adds additional urgency to introduce countercyclical regulation. The questions now are not so much about if, but about how and when, counter-cyclical regulation is introduced. 
As regards banks, Goodhart and Persaud (2008) have presented a specific proposal: increasing Basle II capital requirements by a ratio linked to recent growth of total banks' assets. This is very important in that it provides a clear, simple and transparent rule for introducing counter-cyclicality into regulation of banks. Another virtue of this proposal is that it could be fairly easily implemented, in that it builds on Basle II. Finally, it has the advantage - at the heart of the concept of counter-cyclicality - of linking micro to macro-stability.

In this proposal, each bank would have a basic allowance of asset growth, linked to macro-economic variables, such as inflation and the long-run economic growth rate. It would measure actual growth of bank assets as a weighted average of annual growth (with higher weights for recent growth).

If such a rule is introduced, it is important that it be simple and done in ways that regulators cannot loosen easily, to avoid their becoming "captured" by the general over-enthusiasm that characterises booms.

Three issues arise. Should the focus just be on increases in total bank assets, or should there also be some weighting for excessive growth of bank lending in specific sectors that have grown particularly rapidly (such as recently in real estate)? Often crises have arisen due to excessive lending during boom times to particular sectors or countries (e.g. emerging economies). However, most systemic bank failures have also been preceded by excessive growth of total bank assets.

Second, is the best way to introduce counter-cyclicality through modifying capital adequacy requirements over time? Would not the alternative of increasing provisioning against future losses - as done in Spain and Portugal - be a good option, given that it has much merit, as argued by Ocampo and Chiappe (2003) as well as others? An advantage of using provisions is that their objective is precisely to finance expected losses (in this case through the business cycle) as distinguished from capital, whose objective is to cover for unexpected losses. A disadvantage of using provisions is that accountants object to provisioning of expected losses, especially for asset classes. As global accounting rules are defined, it would be desirable that they pay far more attention to balancing the aim of what is effective for individual and systemic bank stability with their current emphasis on providing information to investors. 
Finally, there is the crucial issue of timing. It seems key to approve such changes soon, while the appetite for regulatory reform remains high. However, their introduction should be done with a lag, so as to avoid increased capital requirements (especially linked to the weighting given to growth in recent years in the G-P formula, which would be high) putting pressure on currently weak banks and accentuating the credit crunch. Indeed, leverage had to be reduced, but this needs to be done gradually.

Some of the least regulated parts of the financial system may have some of the strongest pro-cyclical impacts, including on emerging economies. One such example is the role that hedge funds and derivatives play in carry trade; there is increasing empirical evidence that such carry trade has very procyclical effects (on over or under shooting) of exchange rates of both developed and developing economies, with negative effects often on the real economy (see Goyson, Stahel and Stulz, 2008, as well as Brunnermeir, Nagel and Peterson, 2008, for developed economies; see also, Dodd and Griffith-Jones, 2008 and 2006, for evidence on Brazil and Chile).

For regulation to be comprehensive, as argued above, there should be minimum capital requirements for all derivatives dealers and minimum collateral requirements for all derivatives transactions, so as to reduce leverage and lower systemic risk. Collateral requirements for financial transactions function much like capital requirements for banks.

As discussed above for bank regulation and would be true about introducing greater capital regulations for other actors, the issue of timing is crucial. Regulations need to be approved now, given greater appetite for regulation, but may need to be introduced with a lag, when financial institutions are stronger; doing so now, could weaken financial institutions further and/or accentuate the credit crunch.

An issue to explore is whether regulation of derivatives' collateral and capital requirements should also have counter-cyclical elements. This would seem desirable. It would imply that when derivatives positions, either long or short, were growing excessively (for example, well beyond historical averages), collateral and capital requirements could be increased. An issue to explore is whether this should be done for all derivatives (a far greater task, but consistent with our principle of comprehensiveness) or for derivatives that regulators think can generate systemic risk (shorting of banks' shares) or policy-makers believe can have negative macro-economic effects (carry 
trade leading to over or under shooting of exchange rates); the latter more manageable approach may unfortunately allow growth of derivatives that can have negative externalities, of which financial regulators and economic authorities are unaware at the time.

More broadly, counter-cyclical criteria of regulation may need to be applied to regulations of all transactions and institutions. Besides doing this at the individual institutions or transaction level, it may be necessary, as the BIS (op. cit. 2008) argues, to put greater focus on systemic issues, such as many institutions having similar exposures to common shocks, and risks of contagion between markets and institutions. This is technically challenging, as regulatory requirements for individual institutions would not only need to reflect their own behaviour, but also reflect system-wide developments, such as increasing property prices.

Finally, as argued below, counter-cyclical financial regulation is an increasingly important complement in the modern economy to countercyclical monetary policy. Currently counter-cyclicality is insufficiently used, both in financial regulation and monetary policy, though more widely accepted in fiscal policy, especially in developed economies.

4. Regulation needs to be as tightly co-ordinated internationally as possible.

One of the easiest ways to do regulatory arbitrage is to move activities to other less regulated countries, especially offshore centres. This is particularly, though not only, true for OTC derivatives and hedge funds.

The international community has made important and valuable steps in this direction. However, their efforts are clearly insufficient, given the speed and depth of globalisation of private finance, and its' often negative spill-overs on innocent bystanders.

The discussion of a global financial regulator needs to be put urgently on the international agenda (Kaufman, _; Eatwell and Taylor,_). In the meantime, efforts at increased co-ordination amongst national regulators requires top priority. It is also urgent that developing country regulators participate fully in key regulatory fora, such as the Basle Committee. Given their growing systemic importance, it is absurd and inefficient if they do not. 
5. Compensation of bankers and fund managers needs to be self-regulated or regulated.

As Stiglitz (2008) points out, incentive problems are at the heart of the boom-bust behaviour of financial and banking markets. A large part of bonuses are tied to short-term profits and are one-sided, positive in good times and never negative, even when big losses occur (Roubini, 2008). Such asymmetries seem even stronger in institutions such as hedge funds, where managers fees rise very sharply if profits are very high, but fall mildly with poor performance, encouraging excessive risk-taking and leverage (Kambhu et al, 2007 op. cit and Rajan, 2005).

There is increased consensus that high remuneration, and its' link to short term profits, contributes to boom-bust behaviour of financial markets. Thus the FSF Report (2008, op. cit) quoted above recommends, that "Compensation arrangements often encouraged disproportionate risk-taking with insufficient regard to long-term risks.” Several senior figures in Wall Street and the City of London are arguing for a radical rethinking of compensation schemes (Lewitt, 2008). It is interesting that even the Institute of International Finance (that represents major banks) recognizes the same distortions caused by compensation schemes as the FSF Reports, though as could be expected it is opposed to regulators reforming compensation models (Cornford 2008).

It is positive that the FSF Report recommends that regulators should work with market participants to mitigate risks due to inappropriate incentive structures. This is very encouraging, but it seems unclear that market participants will voluntarily accept such changes, due to collective action and other problems.

There is another negative effect of short-term bonuses, less often highlighted. This is that in good times, banks and other financial institutions have very high profits, but a large part of these are not capitalized, or paid to shareholders. They are paid as very high bonuses. As Wall Street analyst Lewitt (2008) put it "Too much capital is allowed to exit banks in the form of cash compensation.” Banks are bled of capital in good times making less capital available in bad times. When a crisis comes, bail-outs occur to help re-capitalize the banks, paid by the public sector and ultimately by taxpayers. It in fact could be argued that taxpayers are paying ex-post for excessive bonuses. This gives an additional rationale for regulating 
compensation structure. In fact, very high short-term bonuses are creating moral hazard for three reasons; firstly, they encourage excessive risk-taking. Secondly, by bleeding banks of potential capital, they make the need for costly public bail-outs more likely. Finally, if banks have losses due to excessive risk-taking, they may well, in the future, pay less taxes. These two latter effects are not traditionally reflected in the literature.

There could be easy solutions to this problem, including providing only a fixed basic salary on a monthly basis, and accumulating bonuses in an escrow account like a short-term pension fund. These could be cashed only after a period equivalent to an average full cycle of economic activity has taken place, independently if the person stays with the firm or not. The incentives would change towards making medium or long term profits, and the excessive risk-taking linked to short-term bonuses - where large payments are obtained upfront and no costs are paid when losses take place - would be significantly reduced.

There are of course some technical issues on how this could best be implemented. These could be quite easily overcome. However, the key problem will be political, to overcome the resistance of bankers and fund managers. Given the magnitude of the current crisis, its' damaging effects on the real economy - especially in major developed countries - this may be the best of times to move forward. The self regulatory route (by the industry itself) could be tried, but we are sceptical it would bring meaningful results; action by regulators seems essential. In the long term, financial institutions and the financial system will actually benefit from a change in compensation schemes. It is the problems of externalities, collective action and principal agency that may inhibit market agents from reaching a better outcome from their collective perspective. Regulators therefore need to do it for them. This would benefit financial and macro-economic stability and even the stability of individual financial institutions. As argued above, there is also a case for regulating compensation to protect tax payers from possible future bail-outs, and from reduced tax payments by banks due to future losses. 


\section{IV: LIQUIDITY AND SOLVENCY}

Reform proposals put forward by national and international regulatory authorities have tended to include calls for banks and investment banks to raise capital to offset losses and write-downs on mortgages, mortgagebacked securities and other assets that have fallen in value. In these discussions, capital is viewed as the sole cushion for financial institutions and their shrinking capital base is increasingly viewed as a threat to systemic solvency. The ongoing pressure on capital is also seen as impeding efforts to revive credit flows and maintain economic activity.

The severity of the threat to institutional solvency led many to question the ability of the Fed and other central banks to defuse the credit crunch and stem the decline in asset prices. Many assumed that the US problem had shifted from a liquidity crisis to a solvency crisis. While a continuation of liquidity support is seen as necessary, that support appears to be of limited value in terms of either ending the crisis or moderating its current and potential negative impact on the real economy. Solutions increasingly have turned to proposals for government intervention to protect the solvency of systemically important institutions.

But beyond the immediate issue of crisis management, the complementary roles of central bank liquidity as well as capital and holdings of liquid assets as cushions for private financial institutions remain critical issues for reform. As discussed in Section III, reform proposals must include ways to restructure capital and liquidity requirements for depository institutions to moderate their procyclical impact and make them function as a countercyclical instrument of soundness regulation. And, as discussed in section II, we believe that, given the sizable shift in savings and investment flows from banks to institutional investors, the transmission belt for both regulatory and monetary policy initiatives must be extended to reach all segments of the financial system. In this section, we expand these discussions of institutional capital and liquidity and the liquidity cushion provided by central banks to indicate the direction we think further reform proposals should take to restore and bolster financial stability.

1. The role of capital in a market-based system 
Assessments of the role capital plays in guarding the soundness of the financial system have tended to focus on the balance sheets of depository institutions. It should be noted, however, that before 1983 there had been no statutory basis in the US for proscribing the amount of capital banks were required to hold against assets and capital requirements had tended to be ignored in most other countries as well. With the threat of default and the proliferation of non-performing loans on developing country debt in the early 1980s, the US Congress directed the Fed to set limits on banks' assets in relation to capital and this, in turn, led to negotiations with other developed countries that resulted in the adoption of the Basel Agreement on Capital Adequacy in 1988.

But rules governing capital adequacy for banks have not provided the systemic protection that was expected. Because of the rapid increase in outstanding securitized mortgages and other asset-based securities as well as the explosive growth of derivatives, trading and investment in marketable securities has become the dominant activity in US financial markets. However, as has been demonstrated repeatedly since the crisis erupted in the summer of 2007, marketability does not mean that an asset can be sold at the expected price - or even sold at all - and the wider applicability of regulations associated with trading activity may have intensified the inherent procyclical bias of the market-based system that has evolved over the last several decades in the US.

One of the requirements applicable to traded assets is that they be marked to market as prices change. Unlike bank loans held in portfolio at face value, traded assets - including those held by banks - require charges against capital when their prices drop. As a result of the wider applicability of capital charges, the shrinkage in credit flows through banks and their rechanneling through capital markets tended to exacerbate the pressure on capital as the sub-prime mortgage crisis spread. And it increased the potential that this credit crisis would deteriorate into a solvency crisis more rapidly than in earlier periods and affect a wider group of institutions.

Indeed, the resulting threats to the solvency of systemically important nondepository institutions have made clear that the focus on banks' capital position is incomplete. The role of capital in a transformed, market-based system is a parallel concern. Thus we argue that there is need to reexamine the role of capital in a systemic context and ensure that countercyclical capital requirements are developed that will bolster the soundness of all 
financial institutions and activities. But we note that when and how much capital should be held by individual institutions is increasingly related to the level of liquidity in the system as a whole, as well as the level of their holdings of liquid assets.

\section{Maintaining liquidity in a market-based system}

Because capital is a scarce resource and one that is automatically depleted when losses are written off, liquidity requirements were used by central banks and regulators as a critical tool to protect capital in the period before deregulation made such quantitative measures suspect. The Federal Reserve's recent call for investment banks to shore up their balance sheets with more liquid assets underscores the belated recognition that capital alone is an insufficient cushion against the threat of insolvency (Guerrera and van Duyn, 2008). However, the Fed's concern about illiquid balance sheets may come too late. The systemic nature of the current crisis suggests that efforts by individual institutions or sectors to increase their holdings of liquid assets may be ineffectual if the central bank is unable to inject liquidity into critical markets.

Designing a countercyclical regulatory system will require reexamining the role and effectiveness of liquidity requirements for individual institutions and sectors as well as the channels the central bank uses to provide liquidity. The shift from a bank-based to a market-based system has obscured the fact that, in the US before the 1980s, the systemic cushion for the financial sector was bank reserves. One of the major reforms of the Federal Reserve Act of 1913 was to require banks to hold a given percentage of their reserves with their regional Federal Reserve banks rather than as deposits with larger private banks in so-called "reserve cities". As the Federal Reserve System grew and evolved during the 1920s and 1930s, the Fed no longer required banks to pay-in reserves; it created and extinguished those reserves by undertaking open market operations on its own initiative. Changes in reserves became the primary tool that allowed the Fed - as former Fed Chairman William McChesney Martin phrased it - to take away the punch bowl when the party got rowdy and bring it back in when spirits were flagging. In other words, the overreaching objective that had evolved within the Fed itself in its formative years was a commitment to countercyclical monetary policy using bank reserves and open market operations as the tools for implementing that objective. 
In 1951, when banks held 65 percent of financial sector assets and liabilities, their reserve balances with the Fed accounted for 11.3 percent of bank deposits and constituted a remarkably comfortable cushion for a segmented financial system in which banks loaned to other financial sectors with whom they were not then in competition. Fifty years later, however, the shift in credit flows away from banks and banks' use of borrowed funds and strategies such as sweep accounts to reduce holdings of deposits subject to reserve requirements had virtually wiped out that cushion. By year-end 2001, banks reserve balances had shrunk to 0.2 percent of their deposits and banks' holdings of credit market assets had fallen to less than half the share they held fifty years before.

The missing monetary cushion has weakened individual financial institutions and made them more vulnerable to stops in external funding. Borrowing and lending among financial institutions through repurchase agreements - another of the rapidly expanding markets developed as the system evolved - has ceased to be an efficient channel for distributing liquidity as institutions' confidence in the solvency of their financial counterparties has eroded. But the missing monetary cushion has also impeded the Fed's ability to provide liquidity to the system as a whole. The Fed is attempting to address the collapse of liquidity in funding markets by continuing to swap treasuries for riskier securities, extending its emergency borrowing program to investment banks, and continuing to provide term loans to banks.

A cushion of reserve balances owned by financial institutions but held by the Fed would be a far more effective way to alleviate the ongoing credit crunch. The soundness of payments among financial institutions made by transferring reserve balances would not be questioned. Moreover, reserve balances would retain their face value despite the erosion of asset prices. Thus an established pool of financial sector reserves held with the central bank would act as a more effective liquidity buffer than the Fed's current ad hoc lending facilities because it would keep open the channels for private funding.

But such a cushion would serve other important purposes as well. The objective of the Fed's current program of liquidity support is to moderate the pressure for asset sales, stem the decline in their prices and thus protect institutional capital. While capital is and will remain a critical tool of soundness regulation as a cushion against insolvency for individual 
institutions, capital alone cannot protect the financial sector as a whole in the event of a systemic crisis. The Fed's struggle to ensure a systemic reach for its efforts to provide liquidity suggests that, in the future, central banks should attempt to build a source of systemic funding within the monetary system that, like reserves, is renewable and will be immediately available to all financial sectors in a downturn. Meanwhile, a new, system-wide reserve management regime would also restore the effectiveness of countercyclical monetary strategies - a reform we believe is no less important than the regulatory reforms we and others have proposed. ${ }^{5}$

In summary, we argue that there is a critical link between liquidity and solvency; that liquidity protects solvency, and that financial stability will require reforms that include comprehensive, countercyclical regulatory and monetary strategies like those we offer here.

\footnotetext{
${ }^{5}$ For discussions of proposals to extend reserve requirements to all financial institutions and the balance sheet changes that would be required, see Thurow 1972; Pollin 1993: D'Arista and Schlesinger 1993; D’Arista and Griffith-Jones 1998; Palley 2000 and 2003, and D’Arista 2002 and 2008.
} 


\section{References}

Andrews, E.L. "In Reversal, Fed Approves Plan to Curb Risky Lending”, New York Times, December 19, 2007.

BIS (Bank for International Settlements). Annual Report. Basel: BIS, 2002, 2003, 2004, 2005, 2008.

. Quarterly Review: International

Banking and Financial Market Developments. Basel: BIS, June 2005; March 2006.

Borio, C. and P. Lowe. "Asset prices, financial and monetary stability: exploring the nexis”. BIS Working Papers, No. 114. Basel: BIS, 2002.

Brunnermeir-----

Cornford, A. “An agenda for financial system reform”. SUNS, South-North Development Monitor, \#6511, July 7, 2008.

D’Arista, J. "Broken Systems: Agendas for Financial and Monetary Reform”. Paper prepared for the $17^{\text {th }}$ Annual Hyman P. Minsky Conference, Credit Markets and the Real Economy: Is the Financial System Working? Levy Institute, Bard College, Annandale-on-Hudson, NY, April 17, 2008.

Rebuilding the Transmission System for Monetary Policy.

Howardsville, VA: Financial Markets Center, 2002

and S. Griffith-Jones. "The Boom of Portfolio Flows to Emerging Markets and Its Regulatory Implications”, in Montes, M. et al., (eds.), Short-Term Capital Movements and Balance of Payments Crises. Helsinki: World Institute for Development Economics Research, 1998.

and T. Schlesinger, “The Parallel Banking System”, in

Transforming the U.S. Financial System: Equity and Efficiency for the $21^{\text {st }}$ Century, G.A. Dymski et al. (eds.). Armonk, NY: M.E. Sharpe, 1993.

DeBrower

Dodd, R. and S. Griffith-Jones. 
Eatwell, J. and L. Taylor. Global Finance at Risk: The Case for

International Regulation. New York: The New Press, 2000.

European Parliament, Committee on Economic and Monetary Affairs. Draft

Report with recommendations to the Commission on Hedge funds and private equity. Brussels: EU, April 18, 2008.

Federal Reserve System. Flow of Funds Accounts of the United States. Washington, DC: Board of Governors of the Federal Reserve System.

Financial Stability Forum (FSF).

Goodhart, C. and A. Persaud.

Goyson--------

Greenspan, A. “Opening Remarks”. Changing Capital Markets:

Implications for Monetary Policy. Kansas City, MO: Federal Reserve Bank of Kansas City, 1993.

Testimony on the Federal Reserve Board's Semi-annual

Monetary Policy Report to Congress. Committee on Banking, Housing and Urban Affairs, U.S. Senate, February 16, 2005.

Griffith-Jones, S.

Guerrera, F. and A. van Duyn. "Fed presses Wall Street banks on liquidity”. Financial Times, August 10, 2008.

Kambhu

Kaufman, $\mathrm{H}$.

Lewitt, M.E. “How to Fix It”. HCM Newsletter, March 2008.

Ocampo, J.A. and ---Chiappe.

Padoa-Schioppa, 
Palley, T. "Asset Price Bubbles and the Case for Asset-Based Reserve Requirements”. Challenge, vol. 46, no. 3, May/June 2003.

Stabilizing Finance: The Case for Asset-Based Reserve

Requirements. Howardsville, VA: Financial Markets Center, 2000

Pollin, R. "Public Credit Allocation Through the Federal Reserve: Why It Is Needed; How It Should Be Done", in Transforming the U.S. Financial System: Equity and Efficiency for the $21^{\text {st }}$ Century. G.A. Dymski et al., (eds). Armonk, NY: M.E. Sharpe, 1993.

Rajan,

Roubini, N.

Silvers, D. "Some Thoughts on the Preogressive Reform of the Financial Regulatory Structure”. (unpublished paper) Washington, DC: AFL-CIO.

Soros, G.

Stiglitz, J.E. 2002

Stiglitz, J.E. 2008

Stiglitz, J.E. and ---Weiss.

Thurow, L. "Proposals for Re-channeling Funds to Meet Social Priorities", in Policies for a More Competitive Financial System, conference proceedings of the Federal Reserve Bank of Boston, 1972.

Tietmeyer, H. “Overview”. Changing Capital Marks: Implications for Monetary Policy. Kansas, City, MO: Federal Reserve Bank of Kansas City, 1993.

U.S. Department of Commerce, Bureau of Economic Analysis. "The U.S. International Investment Position”. Survey of Current Business. Washington, DC: U.S. Department of Commerce, 2006. 
U.S. Treasury Department. Blueprint for Financial Regulatory Reform. Washington, DC: U.S. Treasury Department, March 2008.

White, W.R. "The Need for a Longer Policy Horizon: A Less Orthodox Approach”, in Global Imbalances and Developing Countries: Remedies for a Failing International Financial System, Teunissen, J.J. and Akkerman, A. (eds.). The Hague: Forum on Debt and Development (FONDAD), 2007.

Wolf, M. 